\title{
The Managerial Control Types of Conglomerates and Firm Performance
}

\author{
Hsiang-Tsai Chiang \\ Department of accounting, Feng Chia University \\ No. 100, Wenhwa Rd., Seatwen, Taichung, Taiwan 40724 \\ Email: htchiang@mail.fcu.edu.tw
}

Mei-Chih Lin (Corresponding author)

Ph.D. Program in Business of Feng Chia University and Department of Marketing and Logistics Management

St. John's University.

No. 499, Sec., 4, TamKing Rd., Tamsui Dist., New Taipei City 25135, Taiwan

Tel: +886-02-2801-3131-6582Ｅmail: maylin@mail.sju.edu.tw

Received: February 26, $2011 \quad$ Accepted: April 4, $2011 \quad$ doi:10.5430/ijfr.v2n2p2

\begin{abstract}
This paper investigated the relationship among board leadership structure, shareholder rights, the divergence of responsibilities, and firm performance under a variety of conglomerate-controlling behaviors. Results revealed a negative correlation among chief executive officer (CEO) duality and deviations from stock-control rights, earnings-distribution rights, seat-control rights, and stock-control rights on a single family-controlled company's performance. The ratio of shares held by directors and independent directors significantly correlated with the level of company performance. This may explain the relationship of current board composition in Taiwanese-listed companies' structure and the phenomenon of business performance. The manager-controlled type is common in Taiwan's electronics industry. We determined that, apart from the significant positive correlation between the numbers of independent directors and company performance, the remaining outcomes of the primary variables were not significant. This illustrates that the controller of the company is the professional manager. The correlation between the structure of the board of directors and company performance was found to be minimally significant. However, independent directors were still found to act as important oversight mechanisms.
\end{abstract}

Keywords: Conglomerate, Control type, Board leadership structure, Independent directors, Firm performance

\section{Introduction}

The origins of an enterprise typically involve a founder starting a small-scale business. As a result of successful operational implementation and the use of various resources, the business gradually expands into a larger company. This company may merge with a number of related companies to become a conglomerate.

The previous empirical literature has generally taken group structure as given and studied the consequences induced by its ownership structure. The literature focuses on the relationship between the controlling family's cash flow and voting rights and measures of accounting performance and valuation (Claessens, Djankov, \& Lang, 2000; Faccio \& Lang, 2002: Chang \& Shin, 2007). The literature has also examined whether group membership affects valuation (Khanna \& Rivkin, 2001; Khanna \& Palepu, 2000; Fisman \& Khanna, 2000; Lefort \& Walker, 2000; Claessens et al., 2002; Kim, Lim, \& Sung, 2007; Almeida, Park, Subrahmanyam, \& Wolfenzon, 2011). Little empirical research focuses on managerial control types of conglomerates and how they influence the company's performance. We try to fill this gap with this paper.

This study's conglomerate samples were obtained from the Taiwan Economic Journal database. The definitions of the companies were adopted from the Taiwan Economic Journal, with group members that may be part of one family being the ultimate controllers of their own companies. The pattern of corporate control within the corporation also implies that the company holds substantial control over its business decisions. Such control can be divided into four types: government control, single-family control, joint rule, and managerial control. There are relatively few government-controlled companies, and they often bear the same consideration of political or policy factors, thereby 
affecting the direction of the company's business decisions. Moreover, government-controlled companies are different from standard companies that adopt corporate business profit as the primary objective of policy making. This study provides a comparative analysis of non-governmental types of control to understand whether the leadership structure of the board of directors has differing effects on corporate performance.

Empirical results have shown that company performance will deteriorate if the responsibilities of company chairperson and chief executive officer (CEO) are held by the same person, resulting in agency costs. Taiwan's listed companies have officers serving as chairperson and manager, thus supporting agency theory. The internalization of the CEO has a positive and significant correlation with improving the rate of return on equity, which indicates that if the CEO is a member of the controlling corporation, he or she will consider the best interests of the corporation. The internalization of the company CEO is beneficial in harmonizing company and shareholder interests. The non-alignment of voting-related rights (stock control and seat control) and earnings-distribution rights in Taiwan's listed companies is common. This non-alignment has a significant negative relationship to company performance, which indicates that an inconsistency of goals between policy makers and shareholder wealth would result in agency costs. The numbers of independent directors and company performance are also significantly and positively correlated. This shows that the larger the proportion of independent directors, the more the board can monitor the performance of company management. This result is consistent with the direction of government regulations and policies.

It was determined that a single family-controlled management structure is most prevalent in Taiwan businesses, accounting for $62 \%$ of the sample. Another variable under consideration was the joint-rule patterns in a company. It was determined that they have a dispersed ownership structure and only deviate in relation to stock-control rights, earnings-distribution rights, and company performance. These variables have a significant negative relationship. There was no significant difference in the other variables.

The single family-controlled company had a negative correlation with the CEO duality and the non-alignment of stock-control rights, earnings-distribution rights, seat-control rights, and the company's performance. The ratio of shares held by directors and independent directors was positive and significantly correlated with company performance. This may explain the phenomenon of the current board composition of Taiwan's listed companies, as well as the boards' structure and relationship to firm performance.

The manager-controlled structure is common in Taiwan's electronics industry. It was determined that, apart from the significant positive correlation between the numbers of independent directors and company performance, the remaining outcomes of the primary variables were not significant. This demonstrates that the controller of the company is the professional manager. The correlation between the board of directors structure and company performance was found to be minimally significant. However, independent directors were still found to act as important oversight mechanisms.

The remainder of this paper is organized as follows. The next section is a literature review; this is followed by the methodology, including a description of the sample data and variable measures. The empirical results are then presented. Conclusions and implications are provided in the final section.

\section{Literature Review and Hypothesis Development}

Many aspects of conglomerate firms have been studied. For example, one aspect prevalent in the literature on portfolio theory is appraising diversification of conglomerate firm performance (Smith \& Schreiner, 1969; Sharpe, 1970; Mason \& Goudzwaard, 1976). Other aspects examined include the economic theory of conglomerates (Gort, 1969; Mueller, 1969) and legal aspects of conglomerates (Berg, 1965). This paper examines the ownership structure aspect of conglomerates' performance effects.

The conglomerate company rules in this paper were adopted from the Taiwan Economic Journal database (TEJ), using its definition of the ultimate controller. The ultimate controller must meet the following conditions: (a) major shareholders are members of the same family (the primary shareholder implies the top 10 shareholders or holders of 5\% or more of the shares), (b) more than one third of the directors are of the same composition, (c) major management engages in the same class, chairperson or CEO, (d) major shareholders has control or affiliation with real control, and (e) major shareholders has an investment relationship with each other. It can be seen from the above definition that there is a close relationship among the group members of the company.

The corporation implies that the group members are closely related as to leadership structure and business decision-making power. However, there are different types of control. Control within the corporation type, which holds substantial control over a company, can dictate the company's business decisions.

The definition of the companies was adopted from the Taiwan Economic Journal, with group members that may be part of one family being the ultimate controllers of their own companies. The pattern of corporate control within the 
corporation also implies that the company holds substantial control over its business decisions. Such control can be divided into four types: government control, single-family control, joint rule, and managerial control. There are relatively few government-controlled companies, and they often bear the same consideration of political or policy factors, thereby affecting the direction of the company's business decisions. Moreover, they differ from standard companies that adopt corporate business profits as the primary objective of policy making. This study provides a comparative analysis of non-governmental types of control to understand whether the leadership structure of the board of directors (BOD) has differing effects on corporate performance.

Single-family control is the most common type of conglomerate in Taiwan. This type of company is ultimately controlled by members of the family (including relatives and the control of legal persons) and has the advantage of an absolute majority with which other shareholders (if there are any) cannot compete. The controlling family members regularly appoint the BOD. There is also typically a monopoly, with most directors being family members (it is common to see one-half or more of the board members be members of the family). As a result, family members completely dominate board decision making. The controlling family members also often hold key company positions, including those of CEO, chief financial officer (CFO), and other positions, to exercise even more control of the company's operations.

Jointly managed companies often have a more dispersed ownership structure. No single group of shareholders has the ultimate majority advantage. In this case, the ultimate controller would need to seek additional support from shareholders, so two or more groups usually control the board.

Manager-controlled companies are the most common type of conglomerate in the Taiwan electronics industry. The ultimate controller is required to have a professional and/or technical background. Apart from being appointed as the director, the ultimate controller is also the key person the company relies on for the practical operation of the company. Therefore, the ultimate controller serves in a senior position (CEO, CFO, or research and development (R\&D) director).

As can be seen, the composition of the board completely depends on the company type. The impact of the composition of the board on the company's operating performance is the focal point of this study. Claessens et al. (2000) investigated the influence of controlling shareholders in listed companies in Taiwan when the family controls the board. They found that the family would apply a pyramid ownership structure to ensure that they have management control. This includes pyramid shareholding for the use of cross-shareholdings. As a result, their voting rights count more than their cash flow rights. The greater the difference between the cash flow rights and voting rights of the controlling shareholder, the lower the value of the company (Claessens et al., 2002). In addition, because of the family structure, the family shareholders and agents (family, CEO) have the same interests and, thus, reduce costs while increasing performance (Demsetz \& Lehn, 1985; Westphal, 1999).

A family CEO may be more competitively advantageous than a professional manager is in relation to acquiring the unique resources required by the company. This is especially true in developing countries that have weak support for market access, because resources may not normally come from official channels (such as banks); these countries are in need of acquiring non-formal private networks (such as the Enterprise Group) (Peng, 2003). Although the family managers can reduce agency conflict, they also have an incentive to favor themselves and their family shareholders. This may result in reduced cash expenditures on investment strategies (Fama \& Jensen, 1983; McConnell \& Servaes, 1990), making the family-controlled company and its sales growth negatively correlated with poor financial performance (Oswald, Muse, \& Rutherford, 2009).

In conclusion, the views reflected in the literature regarding the impact of family control on a company's business performance are inconsistent. Therefore, this paper will use different types of control of conglomerate companies to investigate the impact of the BOD's composition on business performance.

\subsection{CEO Duality}

With regard to the correlation between board leadership structure and corporate performance for CEO duality, agency theory suggests that when the company owner is the CEO, and the manager is the agent, all requests for remaining compensation from the company will create agent losses. This means that managerial behavior will not be considered part of the compensation for the largest shareholder, unless there is an implementation of an appropriate governance structure to protect the interests of the shareholders (Jensen \& Meckling, 1976). Safeguarding the interests of the shareholders is the chairperson of the board, who is not controlled by the CEO. There may also be an appropriate incentive program, so that the CEO and shareholders have the same interests (Williamson, 1985).

Stewardship theory has a different point of view regarding effective board structure. The Butler model is built into the manager model. Unlike in agency theory, managers are assumed to be completely economically rational (Muth \& 
Donaldson, 1998). Managers trying to achieve high performance may meet and try to take action to benefit shareholders through profits (Donaldson \& Davis, 1991).

Regarding the impact of CEO duality on company performance, empirical studies have demonstrated different results. CEO duality reduces the board oversight of the CEO and, thus, company performance will be adversely affected (Levy, 1981; Dayton, 1984). Since operating conditions for the operators have information superiority, they cannot really assess and control the behavior of the owner or operator. This will create the possibility of speculation (Williamson, 1985). This reciprocal relationship, as chairperson and CEO, is found to be independent. However, if CEO duality prevails, then the reciprocity of the board will be compromised (Donaldson \& Davis, 1991). In contrast, one study claimed that company CEO duality might reduce conflicts and improve corporate performance (Anderson \& Anthony, 1986; Donaldson \& Davis, 1991; Davis, Schoorman, \& Donaldson, 1997).

At present, there are no conclusive findings on the relationship between CEO duality and company performance. The current study is not intended to determine the influence of the chairperson and the CEO on company operating performance, but rather to establish the following hypothesis:

H1: CEO duality and firm performance are related.

\subsection{The Internalization of the CEO}

Individuals or groups obtain, and are engaged in, decision making in public companies where control is the result of the purchase of company shares. The ultimate controller has the most influence on corporate decision making. Internalization refers to the CEO. The CEO is the ultimate controller (Lee, 2007). Internalization of the CEO means the CEO represents the ultimate controlling family or commissioning team. Therefore, the CEO should allow for collective interests to take precedence over individual interests. If a $\mathrm{CEO}$ is part of the family, he or she can quickly integrate the interests of the company and will achieve better performance (Anderson \& Reeb, 2003). However, because some family businesses prefer their family members to work in the company and reject the use of external professional managers, they may adopt non-optimal investment strategies (Singell, 1997). Chang and Shin (2007) suggested that there is no relation between controlling family ownership and firm performance.

This study is not intended to determine the impact of a CEO on the company's operating performance, but to establish the following hypothesis:

$\mathrm{H} 2$ : The internalization of the CEO is related to firm performance.

\subsection{Composition of the Board of Directors}

The board of directors plays an important role in the corporate governance system (Fama \& Jensen, 1983). According to agency theory, the BOD is primarily responsible for the supervision and control of management on behalf of the shareholders. Therefore, the board's composition will have an impact on the supervision of the BOD. The number of directors is an important factor in terms of effective corporate governance (Dalton, Daily, Johnson, \& Ellstrand, 1999). A smaller BOD may be more efficient than a larger one, because it can engage in genuine interactions and debates (Firstenberg \& Malkiel, 1994). A larger BOD will increase communication and coordination problems, thus reducing its management control capability over the company (Yermack, 1996; Eisenberg, Sundgren, \& Wells, 1998; Chiang \& Lin, 2007). However, comparatively speaking, a large board size can provide greater mixtures of experts who are more capable of forming with the environment (Goodstein, Gautam, \& Boeker, 1994).

In this study, the size of the BOD and percentage of board ownership in the company are research variables used to understand the scale of the overall impact of the number of directors on the company's operating performance. The results of previous studies are not conclusive; therefore, this study examined the data of listed companies in Taiwan to establish the following hypothesis:

\section{H3: Board size and firm performance are related.}

Since 2002, the Taiwan Stock Exchange and OTC Exchange Center have required newly listed companies to have two independent directors and one independent supervisor to strengthen the corporate governance mechanism. Board members and company management play an important supervisory role in protecting the interests of shareholders. An independent outside director is defined as the addition of foreign powers and responsibilities of directors that has no existing relationship with the company. Internal directors are directors of the company (Clifford \& Evans, 1997).

Stewardship theory states that inside directors contribute to the BOD because they provide expertise and talent and are more familiar with the quality of the CEO's decisions about the company. (Wagner III, Stimpert, \& Fubara, 1998). Studies have illustrated that a higher ratio of outside directors can reduce the probability of the company's manager perpetrating financial fraud by managing earnings (Beasley, 1996; Peasnell, Pope, \& Young, 2005; Klein, 2002). A 
higher ratio of outside directors also has a positive relationship to firm performance (Pearce \& Zahra, 1992). Thus, the following hypothesis is established:

H4: The number of independent directors and firm performance are positively related.

\subsection{Stock-Control Rights}

Stock-control rights imply the right to vote (voting rights), which is a way to control company decision making. The right to vote is related to a person's holdings. A two-way cross-shareholding structure is composed of indirect shareholdings through pyramid structures. Control of a company is related to cash equity investment, the acquisition of power of attorney to obtain shareholder voting rights, and seats on the board. The seat in control of direct and indirect ownership is the combined result of acquisition of the power of attorney and complete control of the company. Earnings-distribution rights, also known as cash flow rights, occur because shareholders are entitled to dividends (Lee, 2007).

The literature on corporate ownership shows that the separation between ownership and control has an important implication for firm performance (La Porta, Lopez-de-Silanes, Shleifer, \& Vishny, 2002; Claessens et al., 2002; Baek, Kang, \& Park, 2004). The literature suggests that pyramidal ownership may reduce firm performance (e.g., Claessens et al., 2002; Joh, 2003).

Stock-control rights and seat-control rights rest with the ultimate controlling power of the company's resources. The earnings-distribution right represents the final allocation of the right to control. If the two were similar, the interests of policy makers and decision-making consequences related to objectives and shareholder wealth would be more consistent and less likely to generate agency costs, and vice versa. Therefore, deviations from these two indicators could be used as the ultimate controlling agency cost index (Lee, 2007). Thus, the following hypotheses are established:

H5: The non-alignment of stock-control rights and earnings-distribution rights is negatively related to firm performance.

H6: The non-alignment of seat-control rights and stock-control rights is negatively related to firm performance.

\section{Data and Methodology}

\subsection{Data}

In this study, data were obtained from the Taiwan Economic Journal database and the 2008 Taiwan Stock Exchange of listed and over-the-counter (OTC)-traded companies. This database did not contain financial companies. The original number of companies was 1,225. Thirty-one companies were deleted from the database, and there were 19 government-control-type companies. There were 1,175 companies in the analyzed database.

In this paper, Taiwan listed companies were grouped and compared to the first members of the group. The list was composed of 724 companies, where 451 were not members of the group. This study involved a comparative analysis using three different types of controls to understand whether the leadership structure of the BOD would have a differing effect on corporate performance. There were 449 companies under single-family control (more than $62 \%$ of the database). Ninety-four companies had joint rule and 181 companies were manager controlled.

\subsection{Variable Definitions}

\subsubsection{Company Performance}

Company performance is the return on total assets (ROA) (net profit / average total assets $\times 100 \%$ ) and return on equity $(\mathrm{ROE})$ (net profit / average equity $\times 100 \%$ ) as a measure of company performance variables. These are the dependent variables in this study.

\subsubsection{CEO Duality (DUAL)}

Holding the position of managing director by the chairperson implies that the posts of a company's CEO and chairperson are held by the same person; this is the dummy variable. When the company is set to 1 , the CEO duality is 0 . According to agency theory, CEO duality and corporate agency costs will have a negative relationship to performance. Therefore, we expect a negative sign. Conversely, the basis of stewardship theory is positive expectations.

\subsubsection{The Internalization of the CEO (INCEO)}

INCEO implies the ultimate control of the internalization. A family member is in the CEO position; this is the dummy variable. When the CEO is set to 1 , the internalization is 0 . In such cases, the CEO will be making business decisions to control the collective interests of the team and will be considering the priority of personal interests. These decisions will be consistent with the majority of shareholders. Therefore, a positive and a negative sign will be expected. 


\subsubsection{Board Size (BS)}

BS as the total number of company directors and supervisors was used to measure variables. In the literature, the relationship between the number of board members and size of board and firm performance is not conclusive; therefore, one can expect both a positive and a negative sign.

\subsubsection{Board Holdings (BH)}

$\mathrm{BH}$ refers to the number of board ownership / number of shares outstanding at the year-end. Previous research has indicated that the relationship between shares held by directors and firm performance is not conclusive; therefore, expect a positive and a negative sign.

\subsubsection{Independent Director Number Tatio (IDS)}

IDS equals BOD for the company's total number of independent board members / total number of board members. The IDS is independent of the independent BOD for the company management team. Monitoring performance and the literature illustrate a positive number representing the majority view; therefore, the expected sign is positive.

\subsubsection{Difference in Stock/Earnings (DSE)}

DSE is the stock-control right, or the earnings-distribution right. Stock control, also known as the right to vote, refers to a company being controlled by the ultimate controlling shareholding ratio. Earnings distribution is also known as cash flow rights; this implies those who ultimately control the distribution of earnings enjoyed by the right. If the said shares for positive control and cash flow rights deviate from the situation, the company should have a negative relationship with business performance. Therefore, we expect a negative sign.

\subsubsection{Difference in Seats/Stocks (DSS)}

DSS is equal to the seat-control right, or the stock-control right. Which seats are in control of the ultimate controller of a company? Is it the director number or total director number, or the board representation within the family? If the number of seats for positive control deviates from the current situation, the company should have a negative relationship with business performance. Therefore, we expect a negative sign.

\subsubsection{Company Size (SIZE)}

SIZE is the natural logarithm of the total assets of the company. The larger the size of the company, the better its ability to maintain operating performance. Therefore, the expected sign is positive.

\subsubsection{Sales Growth Ratio (SAG)}

SAG is equal to the (net operating income - net pre-operating income) / (initial net operating income) $\times 100 \%$. The higher the revenue growth, the better the operating performance. Therefore, the expected sign is positive.

\subsubsection{Debt Ratio (DEBT)}

DEBT is equal to total liabilities / total assets $\times 100 \%$. The higher the debt ratio, the more subject the company is to higher interest expenses and debt default risk. This would have a negative impact on business performance. Therefore, we expect a negative sign.

\subsection{Regression Model}

This study uses a multivariate regression analysis to examine the relationship of the independent variables to firm performance. The full regression model is as follows:

$\mathrm{Yj}=\beta_{0}+\beta_{1} \mathrm{DUAL}+\beta_{2} \mathrm{INCEO}+\beta_{3} \mathrm{BS}+\beta_{4} \mathrm{BH}+\beta_{5} \mathrm{IDS}+\beta_{6} \mathrm{DSE}+\beta_{7} \mathrm{DSS}$

$$
+\beta_{8} \mathrm{SIZE}+\beta_{9} \mathrm{SAG}+\beta_{10} \mathrm{DEBT}+\varepsilon
$$

Where: $\mathrm{Y}$ is denoted as firm performance and $\mathrm{j}=\mathrm{ROE}, \mathrm{ROA}$.

\section{Empirical Results}

\subsection{Descriptive Statistics}

Table 1 shows the descriptive statistics for the sampled companies. About 30\% of the companies listed in Taiwan are of CEO duality (DUAL), compared with Hong Kong and companies in Asia, where $40 \%$ to 55\% have a chairperson holding the post of CEO (Chen, Cheung, Stouraitis, \& Wong, 2005; Lam \& Lee, 2008). The leadership structure of the U.S. company board shows $70 \%$ to $80 \%$ of companies having a chairperson holding the post of CEO (Rechner \& Dalton, 1991; Rhoades, Rechner, \& Sundaramurthy, 2001). In many European countries, the posts of chairperson and CEO of the company are held by a different person. Only $10 \%$ of United Kingdom listed companies are of CEO duality (Coles, 
McWilliams, \& Sen, 2001; Higgs, 2003; Kang \& Zardkoohi, 2005). CEO duality differences are visible in Asia, Hong Kong, and Taiwan versus U.S. and European companies. Table 1 shows that $45 \%$ of the companies have an INCEO. This is significantly higher than the ratio of CEO duality. This implies that although some companies have the posts of chairperson and CEO held by separate people, the CEO of the company still has ultimate control over the management team appointed.

The average board size (BS) is 9.36 and the average board holding (BH) is $23.4 \%$. The average independent director size (IDS) is 1.33. Since February 2002, Taiwan's laws have required that newly listed companies have at least two independent directors to strengthen corporate governance. This law does not require all listed companies to follow suit. Therefore, independent BODs would not fully achieve the scale of a listed company, which must have at least two independent directors. The average difference in stock/earnings (DSE) of 5.6\% illustrates the difference between share-control rights and cash flow rights in Taiwan listed companies. The minimum is 0 , while the maximum is $74 \%$. This indicates that the difference is a common phenomenon. A small number of companies have serious differences. The difference in seats/stocks (DSS) differs by an average of $25 \%$, with a maximum of $87 \%$. This reveals that Taiwanese listed companies have acquired control of the company and promised to obtain a proxy situation. This is a common phenomenon.

$<$ Table 1 about here $>$

\subsection{The Results of ROA Regression Model}

Table 2 illustrates an analysis table of the ROA linear regression model. The total return on assets is used as a proxy for business performance. In Model (1), the overall sample analysis found that CEO duality (DUAL) and operational performance were negatively correlated. This implies that performance will deteriorate when the same person is used, resulting in agency costs. Therefore, the company chairperson and the CEO are the same person. The study found that listed companies in Taiwan with a chairperson concurrently serving as CEO supported the agency theory. Thus, H1 is supported.

CEO duality and firm performance was found to be negatively related. The INCEO had no significant relationship to corporate performance. Therefore, $\mathrm{H} 2$ was not supported.

The relationship between company performance and board size was not significant. The percentage of shares held by directors had a significant positive relationship. These results support H3. Independent BOD (IDS) and corporate performance have a significantly positive correlation. The larger the scale of the independent directors and supervisors, the more people are required to monitor management's performance. Therefore, better results in company performance supported H4.

Stock control and board control work on behalf of the ultimate controlling power of the company's resources. The surplus represents the final allocation of the right to control who assumes the identity of its shareholders. This is an attempt to control the consequences of the corporate resources. The empirical data illustrated a surplus of Taiwan shares in listed companies, as well as seats deviating from the common shares of deviations. The difference in stock/earnings (DSE) and the difference in seats/stocks (DSS) and firm performance have a significant negative relationship. This may explain that decision making is inconsistent with the goal of shareholder wealth and has generated agency costs. Therefore, the results support H5 and H6.

\section{$<$ Table 2 about here $>$}

Table 2 presents Model (2) and Model (3) results. These show the comparative analysis of the sample conglomerates that found that CEO duality and firm performance factors exhibited a significant negative correlation. The seats of the independent directors and firm performance are significant factors and exhibited a positive correlation. This means that, regardless of groups or non-groups, when the offices of the company chairperson and CEO are held by the same person, performance will deteriorate. However, the larger the scale of independent directors and supervisors, the more the company can exercise its oversight operating levels of performance, and company performance will improve. Ratios of shares held by directors and firm performance in the conglomerate have a significant positive relationship.

This paper categorizes the control of the company into clustering patterns, as in Model (4) for the joint-rule company, Model (5) for single-family control, and Model (6) for the manager-controlled company. A comparative analysis found that cohabitation patterns were only in DSE. Firm performance has a significant negative relationship. The other study variables (including control variables, SIZE, SAG, and DEBT) were not significantly different. Moreover, the percentage of shares held by directors has a significantly positive correlation with the company's operating performance. It showed that the performance would deteriorate when the same person holds the office of the family-controlled company's chairperson and CEO. This supports the agency theory. Single family-controlled and corporate manager-controlled companies would have better performance if the size of the independent BOD was larger. 
The results illustrated that CEO duality is negatively related to firm performance in Taiwan's listed companies. These results support agency theory. The percentage of shares held by the directors had a significantly positive relationship with the company's operating performance, especially in the single-family company. This shows that when a higher percentage of shares is held by directors in the group of a single-family company, the board members and shareholders may have more consistent interests, which may lead to better company performance. In addition to the independent BOD, except for joint-rule companies, the sample of companies and operational performance were significantly positive correlated in relation to the scale of the independent directors and supervisors. These companies are more able to exercise their oversight over company performance levels, resulting in better overall company performance. The difference in stock/earnings and the difference in seats/stocks in the entire sample for the single-family company have a significant negative relationship with corporate performance. There are no significant relationships with firm performance in the manager-controlled company.

\subsection{The Results of ROE Regression Model}

Table 3 presents the ROE linear regression model analysis. This analysis was focused on the return on equity (ROE) as a proxy for business performance. Model (7) presents the overall sample analysis and illustrates that CEO duality (DUAL) and operational performance were negatively correlated. Therefore, this supported the agency theory, which supports H1. The INCEO has a significant positive relationship with firm performance. This supports H2.

The relationship between company performance and board size (BS) is not significant, but the percentage of shares held by directors $(\mathrm{BH})$ does have a significant positive relationship. This partially supports H3. Independent BOD (IDS) and corporate performance have a significantly positive correlation. These results support H4. The difference in stock/earnings (DSE) and company earnings have a negative relationship with business performance. This supported H5.

Table 3 presents the analysis results of the ROE linear regression model. These results illustrate that Taiwan's listed companies' CEO duality and firm performance were negatively related. This supports agency theory. The percentage of shares held by directors and the companies' operating performance have a significantly positive relationship, especially in the single-family company. This illustrates that a higher percentage of shares is held by directors in the single-family company. Consequently, board members and shareholders may hold views that are more consistent with the interests of increasing performance. Independent director numbers of non-group and single-family companies showed positive performance. This performance was significantly related to the independent directors and supervisors, which implies that the larger the size of the companies, the better the performance. The difference in stock/earnings has a significant negative relationship with corporate performance. However, there is no significant relationship with firm performance in the manager-controlled company.

$<$ Table 3 about here $>$

\section{Conclusions}

The main contribution of this paper to the literature is to shed light on the processes of different managerial control types of conglomerates and how they influence firm performance.

This paper used listed Taiwanese companies as the sample of companies to examine the effects of firm performance. Investigated variables included the leadership structure of the boards of directors, the effects of misalignment between stock-control rights, seat-control rights, and earnings-distribution rights. Relevant variables also included revenue growth, debt ratio, firm size variables, and their impact on corporate performance results.

Company data were divided into conglomerates and non-conglomerates. The managerial control types of conglomerates were separated into joint-rule, single-family control, and manager-controlled companies.

The misalignment between seat-control rights and stock-control rights shows the situation wherein someone acquires company control by purchasing powers of attorney from stockholders. This situation exists in Taiwan. Internalization of the boards of directors is also common in Taiwan. The number of independent directors and company business performance have a significantly positive correlation. This shows that the larger the scale of the independent directors, the more they can monitor the performance of company management. Such a result is consistent with the direction of government regulations and policies.

According to the linear cluster regression model, the single family-controlled company is more prevalent in Taiwan than the other types of companies. As for the joint-rule patterns in the company that has a dispersed ownership structure and only deviates from stock-control rights and earnings-distribution rights, company performance has a significant negative relationship. In contrast, a single family-controlled company has a negative correlation with CEO duality, the non-alignment of stock-control rights, earnings-distribution rights, seat-control rights, and company performance. The 
ratio of shares held by the directors and the independent board of directors was positive and significantly correlated with company performance. This may explain the phenomenon of the current board composition in the Taiwan listed company structure and the relationship with firm performance.

Kim et al. (2007) investigated the ownership structure of Korea's chaebols and suggested that if controlling families have greater direct shareholdings in firms, they would have greater contribution to group control. In this paper, we found that a single family-controlled company is more prevalent in Taiwan's conglomerates. A larger percentage of shares held by directors would induce better firm performance in family-controlled companies.

The manager-controlled pattern is common in Taiwan's electronics industry. Therefore, the analysis illustrated that, apart from the significant positive correlation between the numbers of independent directors and company performance, the remaining outcomes of the primary variables were not significant. This explains the controller of the company as the professional manager, while the correlation between the structure of the board of directors and company performance is less significant. However, independent directors are still important as oversight mechanisms.

The empirical results and findings of this paper provide reference for the relevant competent authorities in Taiwan to strengthen corporate governance policy. For instance, independent director size is positively related to corporate performance, which implies that the more independent directors there are, the more they are able to play a monitoring role over the management's performance and, hence, the better able they are to improve company performance. This result is consistent with the policy direction of government regulations on listed companies, but the number of independent directors and supervisors only exists in listed companies after 2002. Hence, this result suggests a gradual integration of applicable requirements for all companies. When the agency problem of the chairperson of the board also serving as the CEO arises, there should be a policy to guide improvement. In addition, differences in the share control of cash flow rights in Taiwanese listed companies exist. The small numbers of companies have serious deviations and departures from the seats. The acquisition of shares to obtain control of the company is also a common phenomenon. In such a situation, a company would have a negative performance impact on the stakeholders. It is also worthy of note that different types of firms have different relationships with business performance. These findings are also relevant to investments of the public and interested parties in relation to decision making.

\section{References}

Almeida, H., Park, S. Y., Subrahmanyam, M. G., \& Wolfenzon, D. (2011). The structure and formation of business groups: Evidence from Korean chaebols. Journal of Financial Economics, 99, 447-475. doi:10.1016/j.jfineco.2010.08.017, http://dx.doi.org/10.1016/j.jfineco.2010.08.017

Anderson, C. \& Anthony, N. (1986). The New Corporate Directors. NewYork: JohnWiley \&Sons, Inc.

Anderson, R., \& Reeb, D. (2003). Founding-family ownership and firm performance: Evidence from the S\&P500. Journal of Finance, 58, 1301-1328. doi:10.1111/1540-6261.00567, http://dx.doi.org/10.1111/1540-6261.00567

Baek, J., Kang, J., \& Park, K. (2004). Corporate governance and firm value: evidence from the Korean financial crisis. Journal of Financial Economics, 71, 265-313. doi:10.1016/S0304-405X(03)00167-3, http://dx.doi.org/10.1016/S0304-405X(03)00167-3

Beasley, M. (1996). An Empirical Investigation of the Relation between Board of Director Composition and Financial statement Fraud. The Accounting Review, 71, 443-460.

Berg, N. (1965). Strategic Planning in Conglomerate Companies. Harvard Business Review 43, 79-92.

Chang, J. J., \& Shin, h.h.(2007). Family ownership and performance in Korean conglomerates. Pacific-Basin Finance Journal, 15, 329-352. doi:10.1016/j.pacfin.2006.07.004, http://dx.doi.org/10.1016/j.pacfin.2006.07.004

Chen, Z., Cheung, Y.L., Stouraitis, A. \& Wong, A.W.S. (2005). Ownership concentration, firm performance, and dividend policy in Hong Kong. Pacific-Basin Finance Journal, 13(4), 431-49. doi:10.1016/j.pacfin.2004.12.001, http://dx.doi.org/10.1016/j.pacfin.2004.12.001

Chiang, M. \& Lin, J. (2007). The Relationship between Corporate Governance and Firm Productivity: evidence from Taiwan's manufacturing firms. Corporate Governance: An International Review, 15, 768-779. doi:10.1111/j.1467-8683.2007.00605.x, http://dx.doi.org/10.1111/j.1467-8683.2007.00605.x

Claessens, S., Djankov, S., \& Lang, L.H.P.( 2000). The separation of ownership and control in East Asian corporations. Journal of Financial Economics, 58, 81-112. doi:10.1016/S0304-405X(00)00067-2, http://dx.doi.org/10.1016/S0304-405X(00)00067-2 
Claessens, S., Djankov, S., Fan, J.P.H., \& Lang, L.H.P.( 2002). Disentangling the incentive and

entrenchment effects of large shareholdings. Journal of Finance, 57, 2741-2771. doi:10.1111/1540-6261.00511, http://dx.doi.org/10.1111/1540-6261.00511

Clifford, P. \& Evans, R. (1997). Non-executive directors: A question of independence, Corporate Governance: An International Review, 5, 224-231.

Coles, J.W., McWilliams, V.B. \& Sen, N. (2001). An examination of the relationships of governance mechanisms to performance. Journal of Management, 27 (1), 23-50. doi:10.1177/014920630102700102, http://dx.doi.org/10.1177/014920630102700102

Dalton, D. R., Daily, C. M., Johnson, J. L \& Ellstrand, A. E. (1999). Number of directors and financial performance: A meta-Analysis. Academy of Management Journal, 42, 674-686. doi:10.2307/256988, http://dx.doi.org/10.2307/256988

Davis, J., Schoorman, D. \& Donaldson, L. (1997). Toward a Stewardship Theory of Management. Academy of Management Review, 22, 20-47.

Dayton, N. (1984). Corporate Governance: The Other Side of the Coin. Harvard Business Review, 62, 34-37.

Demsetz, H., \& Lehn, K., (1985). The structure of corporate ownership: Causes and consequences. Journal of Political Economy, 93, 1155-1177. doi:10.1086/261354, http://dx.doi.org/10.1086/261354

Donaldson, L. \& Davis, J. (1991). Stewardship Theory or Agency Theory: CEO governance and shareholder returns. Australian Journal of Management, 16, 49-64. doi:10.1177/031289629101600103, http://dx.doi.org/10.1177/031289629101600103

Eisenberg, T., Sundgren, S. \& Wells, M. (1998). Larger Board Size and Decreasing Firm Value in Small Firms. Journal of Financial Economics, 48, 35-54. doi:10.1016/S0304-405X(98)00003-8, http://dx.doi.org/10.1016/S0304-405X(98)00003-8

Faccio, M., \& Lang, L. (2002). The ultimate ownership of Western European corporations. Journal of Financial Economics 65, 365-395. doi:10.1016/S0304-405X(02)00146-0, http://dx.doi.org/10.1016/S0304-405X(02)00146-0

Fama, E. F., \& Jensen, M. (1983). Separation of ownership and control. Journal of Law and Economics, 26, $301-326$. doi:10.1086/467037, http://dx.doi.org/10.1086/467037

Firstenberg, P. B. \&\& Malkiel B. G. (1994). The twenty-first century boardroom: Who will be in change? Sloan Management Review, 36, 27-35.

Fisman, R., Khanna, T. (2000). Facilitating development: the role of business groups. Unpublished working paper, Columbia University, and Harvard University.

Goodstein, J., Gautam, K., \& Boeker, W. (1994). The Effects of Board Size and Diversity on Strategic Change. Strategic Management Journal, 15, 241-250. doi:10.1002/smj.4250150305, http://dx.doi.org/10.1002/smj.4250150305

Gort, M. (1969). An Economic Disturbance Theory of Mergers. Quarterly Journal of Business, 83, 624-642.

Higgs, D. (2003). Review of the Role and Effectiveness of Non-executive Directors. The Department of Trade and Industry, London.

Jensen, M. \& Meckling, W. (1976). Theory of the Firm: Managerial Behavior, Agency Costs and Ownership Structure. Journal of Financial Economics, 3, 305-360. doi:10.1016/0304-405X(76)90026-X, http://dx.doi.org/10.1016/0304-405X(76)90026-X

Joh, W., (2003). Corporate governance and profitability: Evidence from Korea before the economic crisis. Journal of Financial Economics, 68, 287-322. doi:10.1016/S0304-405X(03)00068-0, http://dx.doi.org/10.1016/S0304-405X(03)00068-0

Kang, E. \& Zardkoohi, A. (2005). Board leadership structure and firm performance. Corporate Governance; An International Review, 13 (6), 785-99.

Khanna, T., \& Palepu, K. (2000). Is group affiliation profitable in emerging markets? An analysis of diversified Indian business groups. Journal of Finance 55, 867-891. doi:10.1111/0022-1082.00229, http://dx.doi.org/10.1111/0022-1082.00229

Khanna, T., \& Rivkin, J. (2001). Estimating the performance effects of business groups in emerging markets. Strategic Management Journal 22, 45-74. doi:10.1002/1097-0266(200101)22:1<45::AID-SMJ147>3.0.CO;2-F, 
http://dx.doi.org/10.1002/1097-0266(200101)22:1\%3C45::AID-SMJ147\%3E3.0.CO;2-F

Kim, W., Lim, Y., \& Sung, T. (2007). Group control motive as a determinant of ownership structure in business conglomerates: Evidence from Korea's chaebols. Pacific-Basin Finance Journal, 15, $213-252$. doi:10.1016/j.pacfin.2006.05.003, http://dx.doi.org/10.1016/j.pacfin.2006.05.003

Klein, A. (2002). Audit committee, Board of Director Characteristics, and earnings management. Journal of Accounting and Economics, 33, 375-400. doi:10.1016/S0165-4101(02)00059-9, http://dx.doi.org/10.1016/S0165-4101(02)00059-9

Lam, T. L. \& Lee, S. K. (2008). CEO Duality and Firm Performance: evidence from Hong Kong. Corporate Governance: An International Review, 8, 299-316. doi:10.1108/14720700810879187, http://dx.doi.org/10.1108/14720700810879187

La Porta, R., Lopez-de-Silanes, F., Shleifer, A., \& Vishny, R., (2002). Investor protection and corporate valuation. Journal of Finance, 57, 1147-1170. doi:10.1111/1540-6261.00457, http://dx.doi.org/10.1111/1540-6261.00457

Lee, k. (2007). The explanation of corporate governance model. Money Watching and Credit Rating, 36,124-133.

Lefort, F. \& Walker, E. (2000). Ownership and Capital Structure of Chilean Conglomerates: Facts and Hypotheses for Governance. Revista ABANTE, 3, 1, 3-27.

Levy, L. (1981). Reforming Board Reform. Harvard Business Review, 59, 166-172.

Mason, R. H., \& Goudzwaard, M. B. (1976). Performance of Conglomerate Firms: A Portfolio Approach. Journal of Finance 31, 39-48. doi:10.2307/2326393, http://dx.doi.org/10.2307/2326393

McConnell, J. J. \& Servaes, H. (1990). Additional evidence on equity ownership and corporate value. Journal of Financial Economics, 27, 595-612. doi:10.1016/0304-405X(90)90069-C, http://dx.doi.org/10.1016/0304-405X(90)90069-C

Mueller, D. C. (1969). A Theory of Conglomerate Mergers. Quarterly Journal of Economics, 83, $643-659$. doi:10.2307/1885454, http://dx.doi.org/10.2307/1885454

Muth, M. M. \& Donaldson, L. (1998). Stewardship Theory and Board Structure: a contingency approach. Corporate Governance: An International Review, 6, 5-28. doi:10.1111/1467-8683.00076, http://dx.doi.org/10.1111/1467-8683.00076

Oswald, S. L., Muse, L. A. \& Rutherford M. W. (2009). The Influence of Large Stake Family Control on Performance: Is It Agency or Entrenchment? Journal of Small Business Management, 47, 116-135. doi:10.1111/j.1540-627X.2008.00264.x, http://dx.doi.org/10.1111/j.1540-627X.2008.00264.x

Peasnell, K., Pope P., \& Young S., (2005). Board Monitoring and Earnings Management: Do Outside Directors Influence Abnormal Accruals? Journal of Business Finance and Accounting, 32, 1311-1346. doi:10.1111/j.0306-686X.2005.00630.x, http://dx.doi.org/10.1111/j.0306-686X.2005.00630.x

Pearce, J. A. \& Zahra, S. A. (1992). Board composition from a strategic contingency perspective. Journal of Management $\quad$ Studies, 29, 411-438. doi:10.1111/j.1467-6486.1992.tb00672.x, http://dx.doi.org/10.1111/j.1467-6486.1992.tb00672.x

Peng, M. W. (2003). Institutional transitions and strategic choices. Academy of Management Review, 28, $275-296$.

Rechner, P.L. \& Dalton, D.R. (1991). CEO duality and organizational performance: a longitudinal Analysis. Strategic Management Journal, 12 (2), 155-60. doi:10.1002/smj.4250120206, http://dx.doi.org/10.1002/smj.4250120206

Rhoades, D.L., Rechner, P.L. \& Sundaramurthy, C. (2001). A meta-analysis of board leadership structure and financial performance: are two heads better than one? Corporate Governance: An International Review, 9 (4), 311-19. doi:10.1111/1467-8683.00258, http://dx.doi.org/10.1111/1467-8683.00258

Sharpe, W. F. (1970). Portfolio Theory and Capital Markets. New York: McGraw-Hill.

Smith, K.V., \& Schreiner, J. C. (1969). A Portfolio Analysis of Conglomerate Diversification. Journal of Finance, 24, 413-428. doi:10.2307/2325343, http://dx.doi.org/10.2307/2325343

Singell, L. (1997). Nepotism, discrimination, and the persistence of utility-maximizing, owner-operated firms. Southern Economics Journal, 63,904-920. doi:10.2307/1061230, http://dx.doi.org/10.2307/1061230

Wagner III, J., Stimpert, J., \& Fubara, E. (1998). Board composition and organizational performance: Two studies of insider/outsider effects. Journal of Management Studies, 35(5), 655-677. doi:10.1111/1467-6486.00114, 
http://dx.doi.org/10.1111/1467-6486.00114

Westphal, J. D. (1999). Collaboration in the boardroom: Behavioral and performance consequences of CEO-board social ties. Academy of Management Journa,l 42, 7-24. doi:10.2307/256871, http://dx.doi.org/10.2307/256871

Williamson, O. (1985). The Economic Institutions of Capitalism. New York, Free Press.

Yermack, D. (1996). Higher Market Valuation of Companies with a Small Board of Directors. Journal of Financial Economics, 40, 185-211. doi:10.1016/0304-405X(95)00844-5, http://dx.doi.org/10.1016/0304-405X(95)00844-5

Table 1. Descriptive statistics

\begin{tabular}{|c|c|c|c|c|c|c|}
\hline & $\mathrm{N}$ & Minimum & Maximum & Mean & S.D. & Medium \\
\hline ROA & 1175 & -0.912 & 0.453 & 0.051 & 0.118 & 0.058 \\
\hline ROE & 1175 & -3.131 & 0.751 & 0.005 & 0.253 & 0.048 \\
\hline DUAL & 1175 & 0.000 & 1.000 & 0.297 & 0.457 & 0.000 \\
\hline INCEO & 1175 & 0.000 & 1.000 & 0.452 & 0.498 & 0.000 \\
\hline BS & 1175 & 5.000 & 32.000 & 9.363 & 2.264 & 9.000 \\
\hline BH & 1175 & 0.020 & 0.950 & 0.234 & 0.144 & 0.200 \\
\hline IDS & 1175 & 0.000 & 0.714 & 0.133 & 0.149 & 0.000 \\
\hline DSE & 1175 & 0.000 & 0.740 & 0.055 & 0.100 & 0.014 \\
\hline DSS & 1175 & -0.650 & 0.865 & 0.249 & 0.229 & 0.244 \\
\hline SIZE & 1175 & 11.143 & 20.290 & 15.081 & 1.339 & 14.918 \\
\hline SAG & 1175 & -1.000 & 20.548 & 0.036 & 1.051 & -0.038 \\
\hline DEBT & 1175 & 0.015 & 1.115 & 0.367 & 0.180 & 0.355 \\
\hline
\end{tabular}

Notes: ROA: (net profit / average total assets * 100\%). ROE: (net profit / average equity *100\%). DUAL: is a dummy variable that is set to 1 when there is CEO duality and 0 otherwise. INCEO: is a dummy variable that is set to 1 when there is CEO internalization and 0 otherwise. BS: The total number of company directors and supervisors. BH: (the number of board ownership / number of shares outstanding at the year-end). IDS: (total number of independent board members / total number of board members). DSE: (the stock-control right- the earnings-distribution right). DSS: (the seat-control right - the stock-control right). SIZE: the natural log value of the total assets of the company. SAG: (Net operating income - net pre-operating income) / (initial net operating income) * 100\%. DEBT: Total liabilities / total assets * $100 \%$. 
Table 2. ROA regression model analysis

\begin{tabular}{|c|c|c|c|c|c|c|c|c|c|c|c|c|c|}
\hline & $\begin{array}{c}\text { Expected } \\
\text { sign }\end{array}$ & \multicolumn{2}{|c|}{ Model (1) } & \multicolumn{2}{|c|}{ Model (2) } & \multicolumn{2}{|c|}{ Model (3) } & \multicolumn{2}{|c|}{ Model (4) } & \multicolumn{2}{|c|}{ Model (5) } & \multicolumn{2}{|c|}{ Model (6) } \\
\hline & & \multicolumn{2}{|c|}{ Full } & \multicolumn{2}{|c|}{ Non-Conglomerate } & \multicolumn{2}{|c|}{ Conglomerate } & \multicolumn{2}{|c|}{ Joint-rule } & \multicolumn{2}{|c|}{$\begin{array}{l}\text { Single-family } \\
\text { control }\end{array}$} & \multicolumn{2}{|c|}{$\begin{array}{c}\text { Managerial } \\
\text { control }\end{array}$} \\
\hline \multirow[t]{2}{*}{ Intercept } & & -0.300 & $* * *$ & -0.571 & $* * *$ & -0.271 & $* * *$ & -0.167 & & -0.251 & $* * *$ & -0.235 & $* * *$ \\
\hline & & $(0.000)$ & & $(0.000)$ & & $(0.000)$ & & $(0.289)$ & & $(0.000)$ & & $(0.005)$ & \\
\hline \multirow[t]{2}{*}{ DUAL } & $+/-$ & -0.029 & $* * *$ & -0.034 & $* * *$ & -0.020 & $* *$ & -0.025 & & -0.026 & $* *$ & 0.006 & \\
\hline & & $(0.000)$ & & $(0.008)$ & & $(0.045)$ & & $(0.440)$ & & $(0.037)$ & & $(0.740)$ & \\
\hline \multirow[t]{2}{*}{ INCEO } & $+/-$ & 0.010 & & 0.012 & & -0.003 & & 0.030 & & -0.005 & & -0.032 & \\
\hline & & $(0.165)$ & & $(0.323)$ & & $(0.722)$ & & $(0.297)$ & & $(0.646)$ & & $(0.127)$ & \\
\hline \multirow[t]{2}{*}{ BS } & $+/-$ & -0.001 & & 0.000 & & -0.001 & & 0.001 & & -0.001 & & 0.003 & \\
\hline & & $(0.358)$ & & $(0.962)$ & & $(0.561)$ & & $(0.798)$ & & $(0.559)$ & & $(0.429)$ & \\
\hline \multirow[t]{2}{*}{$\mathrm{BH}$} & $+/-$ & 0.061 & $* *$ & -0.101 & & 0.081 & $* * *$ & 0.099 & & 0.105 & $* * *$ & -0.014 & \\
\hline & & $(0.020)$ & & $(0.834)$ & & $(0.008)$ & & $(0.287)$ & & $(0.004)$ & & $(0.835)$ & \\
\hline \multirow[t]{2}{*}{ IDS } & + & 0.097 & $* * *$ & 0.106 & $* * *$ & 0.093 & $* * *$ & -0.114 & & 0.092 & $* *$ & 0.118 & $* *$ \\
\hline & & $(0.000)$ & & $(0.006)$ & & $(0.002)$ & & $(0.282)$ & & $(0.024)$ & & $(0.024)$ & \\
\hline \multirow[t]{2}{*}{ DSE } & - & -0.101 & $* * *$ & -0.285 & $* * *$ & -0.046 & & -0.293 & $* *$ & -0.092 & * & 0.062 & \\
\hline & & $(0.005)$ & & $(0.001)$ & & $(0.263)$ & & $(0.033)$ & & $(0.058)$ & & $(0.456)$ & \\
\hline \multirow[t]{2}{*}{ DSS } & - & -0.048 & $* * *$ & -0.026 & & -0.047 & $* *$ & -0.066 & & -0.056 & $* *$ & -0.029 & \\
\hline & & $(0.006)$ & & $(0.403)$ & & $(0.023)$ & & $(0.302)$ & & $(0.023)$ & & 0.528 & \\
\hline \multirow[t]{2}{*}{ SIZE } & + & 0.029 & $* * *$ & 0.050 & $* * *$ & 0.025 & $* * *$ & 0.018 & $*$ & 0.023 & $* * *$ & 0.023 & $* * *$ \\
\hline & & $(0.000)$ & & $(0.000)$ & & $(0.000)$ & & $(0.090)$ & & $(0.000)$ & & $(0.000)$ & \\
\hline \multirow[t]{2}{*}{ SAG } & + & 0.010 & **** & 0.058 & $* * *$ & 0.006 & * & 0.072 & $* *$ & 0.003 & & 0.182 & $* * *$ \\
\hline & & $(0.001)$ & & $(0.000)$ & & $(0.061)$ & & $(0.036)$ & & $(0.358)$ & & $(0.000)$ & \\
\hline \multirow[t]{2}{*}{ DEBT } & - & -0.204 & $* * *$ & -0.245 & $* * *$ & -0.182 & $* * *$ & -0.173 & **** & -0.154 & $* * *$ & -0.250 & $* * *$ \\
\hline & & $(0.000)$ & & $(0.000)$ & & $(0.000)$ & & $(0.010)$ & & $(0.000)$ & & $(0.000)$ & \\
\hline \multicolumn{2}{|c|}{ Adjusted $\mathrm{R}^{2}$} & 0.186 & & 0.277 & & 0.188 & & 0.099 & & 0.157 & & 0.434 & \\
\hline \multicolumn{2}{|c|}{ F-value } & 27.870 & $* * *$ & 18.266 & $* * *$ & 17.726 & $* * *$ & 2.023 & $* *$ & 9.340 & $* * *$ & 14.798 & $* * *$ \\
\hline 1 & & 1175 & & 451 & & 724 & & 94 & & 449 & & 181 & \\
\hline
\end{tabular}

Notes: ROA: (net profit / average total assets * 100\%). ROE: (net profit / average equity * 100\%). DUAL: is a dummy variable that is set to 1 when there is CEO duality and 0 otherwise. INCEO: is a dummy variable that is set to 1 when there is CEO internalization and 0 otherwise. BS: The total number of company directors and supervisors. BH: (the number of board ownership / number of shares outstanding at the year-end). IDS: (total number of independent board members / total number of board members). DSE: (the stock-control right- the earnings-distribution right). DSS: (the seat-control right - the stock-control right). SIZE: the natural log value of the total assets of the company. SAG: (Net operating income - net pre-operating income) / (initial net operating income) $* 100 \%$. DEBT: Total liabilities / total assets $* 100 \%$. $* \mathrm{p}<.10, * * \mathrm{p}<.05, * * * \mathrm{p}<.01$ 
Table 3. ROE regression model analysis

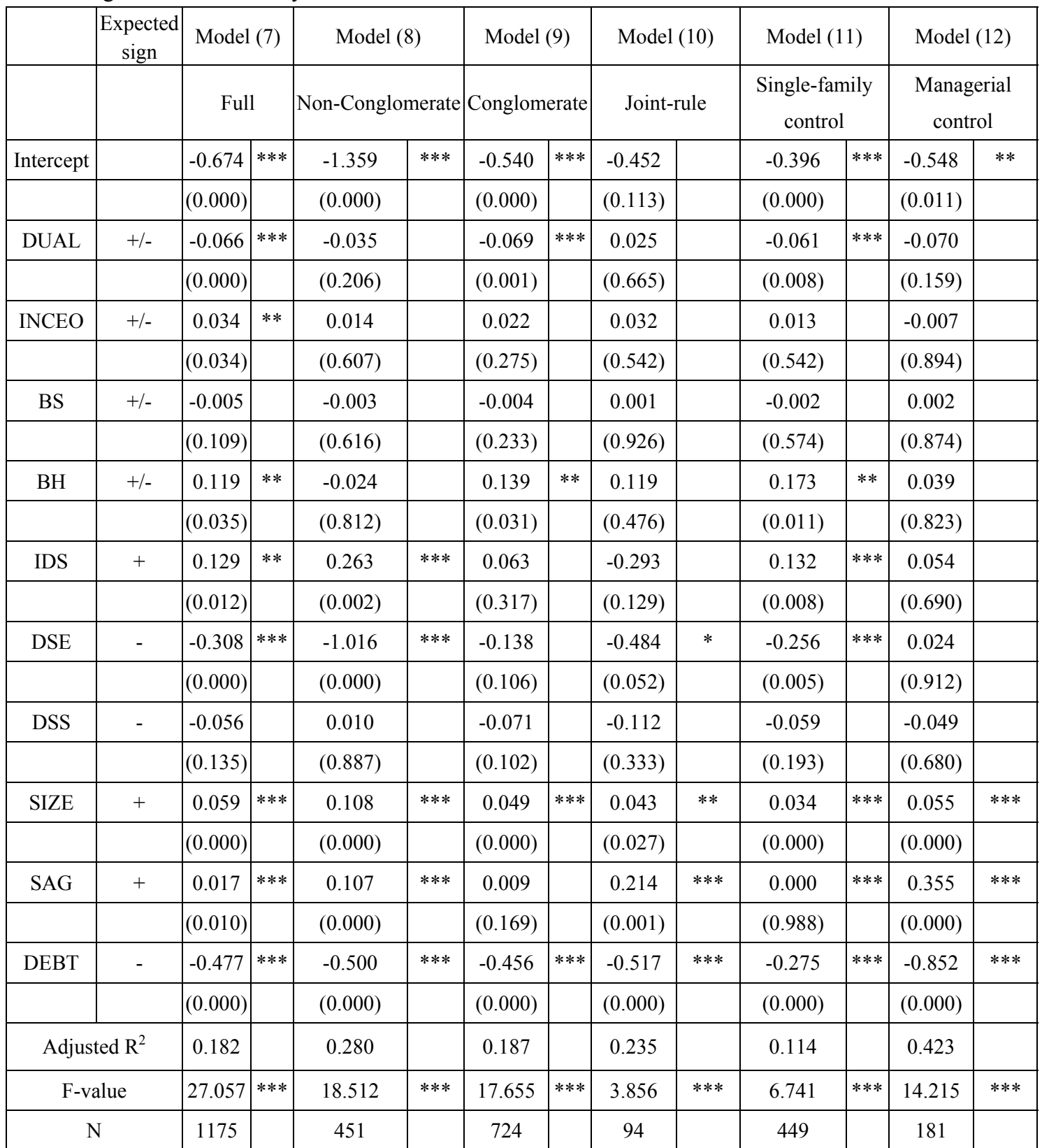

Notes: ROA: (net profit / average total assets * 100\%). ROE: (net profit / average equity * 100\%). DUAL: is a dummy variable that is set to 1 when there is CEO duality and 0 otherwise. INCEO: is a dummy variable that is set to 1 when there is CEO internalization and 0 otherwise. BS: The total number of company directors and supervisors. BH: (the number of board ownership / number of shares outstanding at the year-end). IDS: (total number of independent board members / total number of board members). DSE: (the stock-control right- the earnings-distribution right). DSS: (the seat-control right - the stock-control right). SIZE: the natural log value of the total assets of the company. SAG: (Net operating income - net pre-operating income) / (initial net operating income) * 100\%. DEBT: Total liabilities / total assets $* 100 \%{ }^{*} \mathrm{p}<.10, * * \mathrm{p}<.05, * * * \mathrm{p}<.01$ 